\title{
Depresyon tanılı hastalarda duygusal yeme ve etkileyen faktörler
}

\section{Emotional eating and affecting factors on depression diagnosed patients}

\author{
Seher INALKAÇ ${ }^{1}$ (D) Hülya ARSLANTAŞ ${ }^{2 @(D)}$ \\ ${ }^{1}$ Batman Eğitim ve Araştırma Hastanesi, 72070, Batman-Türkiye \\ ${ }^{2}$ Aydın Adnan Menderes Üniversitesi, Hemşirelik Fakültesi, Ruh Sağlığı ve Hastalıkları Hemşireliği Anabilim Dalı, \\ 09100, Aydın-Türkiye
}

Atıf gösterme/Cite this article as: İnalkaç S, Arslantaş H. Depresyon tanılı hastalarda duygusal yeme ve etkileyen faktörler. ADYÜ Sağllk Bilimleri Derg. 2021;7(3):243-257. doi:10.30569.adiyamansaglik.942978

\section{$\ddot{O} \mathbf{z}$}

Amaç: Çalışma depresyon tanılı hastalarda duygusal yeme ve etkileyen faktörleri belirlemek amacıyla yapılmıştır.

Gereç ve Yöntem: Örneklemi Aralık 2017-Ekim 2018 tarihleri arasında psikiyatri polikliniklerine ayaktan başvuran 240 depresyon tanılı hasta oluşturmuştur. Veriler Kişisel Bilgi Formu, Duygusal Yeme Ölçeği, Gözden Geçirilmiş Sosyal Sorun Çözme Ölçeği ve Stresle Başa Çıkma Tarzları Ölçeği ile toplanmıştır.

Bulgular: Araştırmaya katılan hastaların \%54,2'si kadın olup yaş ortalamaları $(27,52 \pm 12,28)$ 'dır. Araştırmada duygusal yeme ile gözden geçirilmiş sosyal sorun çözme arasında negatif yönde anlamlı ( $p<0,01)$, duygusal yeme ile stresle başa çıkma tarzları arasında pozitif yönde anlamlı ilişki $(p<0,05)$ bulunmuştur.

Sonuç: Hastaların sorun çözme ve stresle baş etme becerileri azaldıkça duygusal yemenin arttığ belirlenmiştir. Hastalara problem çözme becerilerinin ve stresle baş etme tekniklerinin öğretilmesi uygun olacaktır.

Anahtar Kelimeler: Depresyon; Hasta; Duygusal yeme; Etkileyen faktör.

\begin{abstract}
Aim: This study has been done for the purpose of determining emotional eating and affecting factors on depression diagnosed patients.

Materials and Methods: The sample consisted of 240 patients with a diagnosis of depression who applied to psychiatry outpatient clinics between December 2017 and October 2018. Data were collected by using Personal Information Form, Revised Social Problem Solving Scale, Styles of Coping with Stress Scale and Emotional Eating Scale.

Results: \%54.2 of the patients in this research were women and their average age was $(27.52 \pm 12.28)$. In the study, a negative significant relationship was found between emotional eating and revised social problem solving $(p<0.01)$ and a positive significant relationship between emotional eating and coping styles $(p<0.05)$.

Conclusion: It was determined that emotional eating increased as patients' problem solving and coping skills decreased. It would be appropriate to teach the patients problem solving skills and stress coping techniques.

Keywords: Depression; Patient; Emotional eating; Affecting factors.
\end{abstract}

Yazışma Adresi/Address for Correspondence: Hülya ARSLANTAŞ, Aydın Adnan Menderes Üniversitesi, Hemşirelik Fakültesi, Ruh Sağlığı ve Hastalıkları Hemşireliği Anabilim Dalı, Kepez Mevkii, Merkez Kampüs, 09100, Aydın, Türkiye, E-mail: hulyaars@yahoo.com

Geliş Tarihi/Received:22.04.2021 Kabul Tarihi/Accepted:17.08.2021

Yayım Tarihi/Published online:31.12.2021

Bu eser, Creative Commons Atıf-GayriTicari 4.0 Uluslararası Lisansı ile lisanslanmıştır. Telif Hakk1 @ 2021 Adıyaman Üniversitesi Rektörlüğü 


\section{Giriş}

Genellikle ilgisiz davranma, isteksiz olma, duygusal anlamda çökkünlük, zevk alamama, enerji azalması, hayata karamsar bakma, kendini değersiz ve pişman hissetme, suçluluk duygusu yaşama, uyku bozukluğu, iştahın belirgin bir şekilde artması ya da azalması ve cinsel isteksizlik gibi belirtiler gösteren depresyon ile ilgili bozukluklar Türkiye'de ve Dünyada önemli bir halk sağlığı sorunudur. ${ }^{1-3}$ Depresyon toplum sağlığını en çok tehdit eden ruhsal sorunlardan biri olması yanında, toplum içinde giderek yaygınlık göstermesi, kronikleşme riski taşıması, intihar etme olasılığının artması, meydana getirdiği yeti kayb1 ve doğurduğu ekonomik sonuçlar nedeniyle de önemli bir ruhsal problemdir. ${ }^{3}$ Depresyon, kronikleşme riskinin yanı sıra, iş ve sosyal yaşamda meydana getirdiğ $i$ kayıplar, günlük yaşam aktivitelerindeki negatif sonuçlar nedeniyle de yeti kaybı açısından tüm tıbbi hastalıklar arasında dördüncü sırada yer almaktadır. ${ }^{4}$

Yeterli ve dengeli beslenme sağlıklı olabilmenin ön koşullarından birisidir. Büyümek, gelişmek, sağlıklı ve üretken olabilmek için gerekli olan besin öğelerinin vücuda alınıp kullanılması durumuna beslenme denilmektedir. ${ }^{5}$ Beslenme bir ihtiyaçtır ve bu ihtiyacın karşılanması hem biyolojik hem de psikolojik açıdan oldukça önemlidir. Bireyler, öfkelenme ya da kendini baskı altında hissetme vb. gibi bazı duygu durumlarında normalden daha fazla yiyecek tüketme eğilimine sahiptirler. Aynı şekilde yoğun duygu durumlarında (heyecan, korku, aşırı stres vb.) hiç yemek yiyememe de duygu durumlarının beslenme üzerinde bıraktığı etki ile açıklanabilir. $\mathrm{Bu}$ durumlar, psikolojik faktörlerin beslenme üzerindeki etkisi olarak ifade edilmektedir. ${ }^{6,7}$

Yeme bozuklukları; tıbbi, psikolojik ve toplumsal sorunlara yol açabilen, aynı zamanda yaşam kalitesini negatif yönden etkileyen yeme tutumu bozukluklarıdır. ${ }^{8}$ Duygusal yeme; depresyon, yalnız kalma, anksiyete yaşama gibi duygu değişimlerine yanıt olarak gelişen ve çoğunlukla normal zamanlarda tüketildiğinde daha fazla yemek yemeye neden olan psikolojik yeme bozukluğu olarak tanımlanmaktadır. ${ }^{9}$
Duygusal yeme olarak bilinen bu yeme tutumu, ruh halinin kontrol edilebilmesi için besin tüketiminin bir sonucu olarak ortaya çıkmıştır. ${ }^{6}$ Duygu durumlarının iştahın artması ya da azalması üzerinde $\% 30$ ile $\% 48$ oranında artma veya azalmaya neden olduğu bildirilmektedir. ${ }^{10}$

Araştırmalarda farklı duygu durumlarının bireylerin yeme tutumlarını nasıl etkilediği incelenmiştir. Yapılan araştırmalar sonucunda, bireyler arasında bazı farklılıklar gözlense de depresif ruh hali, stres, anksiyete, aleksitimi gibi negatif duyguların genellikle besin tüketimini arttırdığı ve düzenli beslenme alışkanlığını bozduğu tespit edilmiştir. ${ }^{10}$ Duygusal yeme ve etkileyen faktörler üzerinde yapılan araştırmalar, obeziteyi önlemek için olanak sağlayabilecek sağlık eğitimi müdahalelerinin planlanmasında ve hayata geçirilmesinde yararlı olabilir. ${ }^{7,11}$ Bazı duygu durumlarının (sevinç, korku, öfke, hüzün vb. gibi) sindirim ve metabolizma ile birlikte yemenin tüm süreçlerinde yeme motivasyonu, yiyecek sıklığı, yeme miktarı ve yiyecek seçimi gibi yeme yanıtlarını etkilediği saptanmıştır. ${ }^{7,10-21}$ İnsanların beslenme tutumları fizyolojik faktörler dışında psikolojik faktörlerden de etkilenmektedir. ${ }^{22}$ Duygu durumlarının gıda seçenekleri ve yeme davranışı üzerinde güçlü bir etkisi olduğu ve yeme davranışının da duygular üzerinde güçlü bir etkisinin olabileceği genel olarak kabul görmüştür. ${ }^{23}$ Yemek yeme ihtiyacının psikolojik nedenlere mi fizyolojik nedenlere mi bağlı olduğunu belirlemek önemlidir. ${ }^{24}$

Stresin sağlığı doğrudan psikolojik süreçlerin ötesinde etkilediği, aynı zamanda yiyecek seçimi ve alımı gibi sağlık davranışlarındaki değişiklikleri de beraberinde getirdiği belirtilmiştir. ${ }^{25}$ Yüksek depresif belirtilerin duygusal yeme davranışları ile ilişkili olduğu bildirilmektedir. ${ }^{15,18,26} \mathrm{Bu}$ durumdaki kişilerin enerji yoğunluğu daha yüksek besinleri tükettiği ${ }^{6,7,18}$ ve Beden Kitle İndekslerinin de (BKİ) daha yüksek olduğu saptanmıştır. ${ }^{9}$

Alan yazın çalışmaları incelendiğinde depresyon tanılı hastalarda duygusal yeme ve etkileyen faktörleri araştıran herhangi bir çalışmaya rastlanmamıştır. Bireylerin 
depresyon sirasinda fazla yemek yemeleri kilo almalarına ve beraberinde metabolik sendrom riski taşımalarına neden olabilir. $\mathrm{Bu}$ da ilerleyen süreçte bireylerin kan şekerlerinin yükselmesine, tansiyon problemlerine ve diğer fiziksel sağlık problemleri yaşamalarına zemin hazırlayabilir. Bu nedenlerden dolayı depresyon tanılı hastalarda duygusal yeme ve etkileyen faktörleri araştırmak oldukça önemlidir. Yapılan araştırma doğrultusunda duygusal yemeye neden olan faktörleri tanımlamak, obezite önleme ve kilo verme girişimlerine katkıda bulunmak ve bu faktörlere yönelik sağlık müdahalelerini ve ilgili eğitim programlarını önermekte mümkün olacaktır. Depresyon tanılı hastalarda duygusal yemeyi etkileyen faktörleri belirlemek amacı ile analitik kesitsel olarak yapılan bu araştırmanın sorusu;

1. Depresyon tanılı hastalarda duygusal yemeyi etkileyen faktörler nelerdir? olarak belirlenmiştir.

\section{Gereç ve Yöntem}

\section{Araştırmanın tipi}

$\mathrm{Bu}$ çalışma depresyon tanılı hastalarda duygusal yeme ve etkileyen faktörleri belirlemek amacı ile analitik kesitsel olarak yapılmıştır.

\section{Araştırmanın evreni ve örneklemi}

Araştırma Aydın Adnan Menderes Üniversitesi Uygulama ve Araştırma Hastanesi ile Torbali Devlet Hastanesi psikiyatri polikliniklerine ayaktan başvuran, DSM 5'e göre Yeğin (Majör) Depresyon Bozukluğu tanısı almış olan hastalarda Aralık 2017-Ekim 2018 tarihleri arasında yapılmıştır. Epi İnfo Statcalc programına göre "Bir grup ebelik ögrencisinde duygusal yeme ve etkileyen faktörler" yayınına göre "duygusal yemede" beklenen prevalans \%66,9 iken, $\% 90$ güven aralığında, sapma (d) $=0,05$ alındığında belirlenen örneklem büyüklüğ̈̈ 240 olarak hesaplanmıştır. ${ }^{27}$ Hafta içi psikiyatri polikliniklerine başvuran, araştırmaya katılmayı kabul eden ve araştırmaya alınma kriterlerine uyan bütün hastalar polikliniklere ait test odalarında mahremiyetleri göz önünde bulundurularak araştırma örneklemi tamamlanana kadar araştırmaya katılmaya davet edilmiştir. Araştırmaya alınma kriterleri olarak; psikiyatri polikliniğine başvurmuş olması, depresyon tanısı almış olması, soruları anlamasını engelleyecek mental kapasite sorununun olmaması, araştırmaya katılmaya istekli olması, 18 yaş ve üzeri olması, remisyon döneminde olması, araştırmadan dışlanma kriterleri olarak ise; işitme, anlama veya görme sorunları olması, depresyon dışında başka bir ruhsal bozukluk tanısı almış olması olarak belirlenmiştir.

\section{Veri toplama araçları}

Araştırmanın verileri; hastaların sosyo demografik özelliklerini ve duygusal yemelerini etkileyeceğini düşünülen soruları içeren Veri Toplama Formu, Duygusal Yeme Ölçeği (DYÖ), Gözden Geçirilmiş Sosyal Sorun Çözme Ölçeği (TR-SSÇE-G) ve Stresle Başa Çıkma Tarzları Ölçeği (SBÇTÖ) ile toplanmıştır.

\section{Veri toplama formu}

Hastaların sosyodemografik özellikleri, eğitim durumu, çalışabilirlik durumu, medeni durumu, sigara/alkol kullanma durumu, özkıyım girişimi olup olmadığı, daha çok hangi öğünlerde duygusal yeme ihtiyac1 olduğu vb. gibi bilgileri içeren 23 sorudan oluşmuş bu form ilgili literatür taranarak oluşturulmuştur. ${ }^{28,29}$

\section{Duygusal yeme ölçeği (DYÖ)}

Duygusal yeme durumunu ölçen, danışanın kendisinin doldurduğu ölçek Garaulet ve $\operatorname{arkadaşlar1}^{28}$ tarafından geliştirilmiş olup geçerlik ve güvenirlik çalışması yapılmıştır. Dörtlü Likert tipi olan ölçek 10 sorudan oluşmakta olup "0 puan" asla, "1 puan" bazen, "2 puan" genellikle, "3 puan" her zaman şeklinde işaretlenmekte olup ölçekten en düşük "0" en yüksek "30" puan alınmaktadır. Yüksek puanlar kişinin duygusal yiyici olduğunu göstermektedir. Ölçeğin Türkçe geçerlik ve güvenirlik çalışması Arslantaş ve arkadaşları ${ }^{30}$ tarafindan yapılmış olup ölçeğin tümü için alfa iç tutarlık katsayısı 0,84 olarak hesaplanmıştır. $\mathrm{Bu}$ çalışmada ölçeğin Cronbach alfa iç tutarlık katsayısı 0,85 olarak bulunmuştur. 


\section{Gözden geçirilmiş sosyal sorun çözme ölçeği (Tr-SSÇE-G)}

D'Zurilla ve arkadaşları ${ }^{31}$ tarafindan oluşturulmuştur. Ölçeğin Türkçe geçerlik güvenirlik çalışması Eskin ve Aycan $^{32}$ tarafından yapılmıştır. Kısa formu 0 "Benim için hiç doğru değil", 1 "Benim için birazcık doğru", 2 "Benim için kısmen doğru", 3 "Benim için çok doğru", 4 "Benim için tamamen doğru" arasında puanlanan 5 basamakl1 Likert tipi bir ölçek olup 25 maddedir. TR-SSÇE-G, sosyal sorun çözme sürecinin farklı yönlerini değerlendiren ve her biri kendi arasında 5 madde içeren 5 farklı alt ölçekten oluşmaktadır. $\mathrm{Bu}$ alt ölçekler şunlardır: 1. Olumlu sorun yönelimi (OSY), 2. Negatif sorun yönelimi (NSY), 3. Akılc1 sorun çözme tarzı (ASÇT), 4. Dürtüseldikkatsiz sorun çözme tarzı (DDSÇT), 5. Kaçıngan sorun çözme tarzı (KSÇT). TrSSÇE-G'nin kısa formu için ölçek puanları 0 ile 20 puan arasında değişkenlik göstermektedir. Yüksek puanlar etkili sorun çözme becerisini ifade eder. Tr-SSÇE-G'nin kısa formunun alt ölçeklerinin iç tutarlık katsayıları, 0,62 ile 0,92 arasında değişirken test-tekrar test güvenilirlik katsayılarının 0,60 ile 0,84 arasında değiştiği bulunmuştur. $\mathrm{Bu}$ çalışmada ölçeğin Cronbach alfa iç tutarlık katsayısı toplamda 0,75 , alt ölçekler olan; OSY için 0,76, NSY için 0,74, ASÇT için 0,72 , DDSÇT için 0,76 ve KSÇT için 0,73 olarak bulunmuştur.

\section{Stresle Başa Çıkma Tarzları Ölçeği (SBÇTÖ)}

Folkman ve Lazarus'un ${ }^{33}$ geliştirdiği, stresli durumlarda geçerliği kabul edilmiş, özellikle depresyon, yalnızlık ve psikosomatik sorunlar gibi belirtilerle ilişkili olan başa çıkma mekanizmaları ölçeğidir. Şahin ve Durak $^{34}$ tarafindan Türkçeye uyarlanan ölçek 30 maddeden ve 5 alt ölçekten oluşmaktadır. Ölçek, iki ana stresle başa çıkma tarzını ölçmektedir. Bunlar "Probleme yönelik/aktif" ve "Duygulara yönelik/pasif” tarzlardır. Aktif tarzları "Sosyal Destek Arayan Yaklaşım", "İyimser Yaklaşım" ve "Kendine Güvenli Yaklaşım" alt ölçekleri, pasif tarzları "Çaresiz Yaklaşım" ve "Boyun Eğici Yaklaşım" alt ölçekleri göstermektedir. Stresle etkili olarak başa çıkabilme becerilerine sahip kişilerin "Kendine Güvenli Yaklaşım” ve " İyimser Yaklaşım" tarzını, başa çıkamayanların ise "Boyun Eğici Yaklaşım" ve "Çaresiz Yaklaşım" tarzını daha fazla kullandıkları saptanmıştır. Puanların yüksekliği, kişinin o tarzı daha çok kullandığını göstermektedir. $\mathrm{Bu}$ çalışmada ölçeğin Cronbach alfa iç tutarlık katsayısı toplamda 0,68 , alt ölçekler olan; Sosyal Destek Arayan Yaklaşım için 0,68 , İyimser Yaklaşım için 0,69, Kendine Güvenli Yaklaşım için 0,70, Çaresiz Yaklaşım için 0,63 ve Boyun Eğici Yaklaşım için 0,64 olarak bulunmuştur.

\section{Verilerin analizi}

Araştırmanın verileri SPSS 22 (Statistical Package for the Social Sciences) programı kullanılarak analiz edilmiştir. Çalışmanın başında normal dağılım analizleri yapılmıştır. Bu kapsamda Gauss eğrisi değerlendirilmiş ve ortalama puan, minimum ve maksimum puan genişliği, Kolmogorov-Smirnov testi anlamlılık düzeyi hesaplanmıştır. Hastalardan elde edilen verilerin değerlendirilmesinde tanımlayıcı istatistiklerin yanı sıra (Yüzdelik, ortalama, standart sapma) Kruskal Wallis testi, Mann Whitney U testi ve Pearson korelasyon analizi kullanılmıştır. Tip 1 hata düzeyi $p<0,05$ olarak kabul edilmiştir.

\section{Araştırmanın etik yönü}

Araştırmanın yapılması için Aydın Adnan Menderes Üniversitesi Tip Fakültesi Girişimsel Olmayan Araştırmalar Etik Kurulu Başkanlığı'ndan onay (Protokol No: 2017/1213), İzmir İl Sağlı Müdürlüğünden ve Aydın Adnan Menderes Üniversitesi Araştırma ve Uygulama Hastanesi Psikiyatri Kliniğinden izinler alınmıştır. Örnekleme alınma kriterlerine uyan hastalara açıklama yapılmış olup hastaların sözlü ve yazılı onamı dahilinde anketler uygulanmıştır. Çalışma Helsinki İlkeler Deklarasyonunda belirtilen etik kurallara uygun olarak gerçekleştirilmiştir.

\section{Bulgular}

Depresyon tanılı hastaların sosyo demografik özelliklerinin dağılımı Tablo 1'de görülmektedir. 
Tablo 1. Depresyon tanılı hastaların sosyo demografik özelliklerinin dağılımı.

\begin{tabular}{|c|c|c|}
\hline $\begin{array}{l}\text { Katılımcıların Sosyo Demografik } \\
\text { Özellikleri }\end{array}$ & $\mathbf{n}$ & Ort \pm SS \\
\hline \multirow[t]{2}{*}{ Yaş } & 240 & $27,52 \pm 12,28$ \\
\hline & $\mathbf{n}$ & $\%$ \\
\hline \multicolumn{3}{|l|}{ Cinsiyet } \\
\hline Kadın & 130 & 54,2 \\
\hline Erkek & 110 & 45,8 \\
\hline \multicolumn{3}{|l|}{ Medeni durum } \\
\hline Bekar & 186 & 77,5 \\
\hline Evli & 46 & 19,2 \\
\hline Dul/Boşanmış/Ayrı yaşıyor & 8 & 3,3 \\
\hline \multicolumn{3}{|l|}{ Eğitim düzeyi } \\
\hline Okuryazar değil & 2 & 0,8 \\
\hline Okuryazar & 12 & 5,0 \\
\hline İlköğretim & 13 & 5,4 \\
\hline Lise & 125 & 52,1 \\
\hline Üniversite & 88 & 36,6 \\
\hline \multicolumn{3}{|l|}{ Aile Durumu } \\
\hline Çekirdek aile & 203 & 84,6 \\
\hline Geniş aile & 37 & 15,4 \\
\hline \multicolumn{3}{|l|}{ Evin kime ait olduğu } \\
\hline Kendi evi & 165 & 68,8 \\
\hline Kira & 73 & 30,4 \\
\hline Lojman & 1 & 0,4 \\
\hline Diğer & 1 & 0,4 \\
\hline \multicolumn{3}{|l|}{ Sosyo-ekonomik düzey } \\
\hline Gelir giderden az & 79 & 32,9 \\
\hline Gelir gidere denk & 136 & 56,7 \\
\hline Gelir giderden fazla & 25 & 10,4 \\
\hline \multicolumn{3}{|l|}{ Çalışabilirlik durumu } \\
\hline Düzenli çalışıyor & 39 & 16,3 \\
\hline Düzensiz çalışıyor & 37 & 15,4 \\
\hline Çalışmiyor & 159 & 66,3 \\
\hline Emekli & 5 & 2,1 \\
\hline
\end{tabular}

Depresyon tanılı hastaları sosyo demografik özellikleri ile duygusal yeme ölçeği puan ortalamaları karşılaştırıldığında yaşın $\quad(\mathrm{r}=-0,225 ; \quad p=0,000), \quad$ cinsiyetin (MWU $=5434,500 ; p=0,001)$ ve medeni durumun $(\mathrm{KW}=8,459 ; \quad p=0,015)$ duygusal yemeyi etkilediği bulunmuştur (Tablo 2).

Depresyon tanılı hastaların bazı klinik özellikleri ile duygusal yeme ölçeği puan ortalamaları karşılaştırıldığında özkıyım girişiminin $\quad(\mathrm{MWU}=5563,000 ; \quad p=0,003)$, yediklerinin miktarını sinırlamakta sorun yaşayanların $(\mathrm{MWU}=3189,500 ; p=0,000)$, aç olmadığ 1 halde yemek yeme atakları geçirenlerin (MWU=3195,500; $p=0,000$ ), uykusunu ertelemek için gece geç saatlerde yemek yiyenlerin $\quad(\mathrm{MWU}=4854,000$; $p=0,000)$, doyduktan sonra da yemek yemeye devam edenlerin $\quad(\mathrm{MWU}=3674,000$; $p=0,000)$, yemek yeme isteği anlık ve dürtüsel olanların (MWU=4614,500; $p=0,000)$, yemek yerken duygularının onları yönlendirdiğini düşünenlerin (MWU $=4866,000 ; \quad p=0,000), \quad$ kilo alip vermenin ruhsal durumları üzerinde etkisi olanların $\quad(\mathrm{MWU}=3591,000 ; \quad p=0,000)$, duygusal olarak yeme alışkanlığını fark ettiğinde bir sağlik profesyoneline başvuranların (MWU=2519,500; $p=0,005$ ), bazı yiyecekleri gizli gizli yiyenlerin (MWU $=2155,500 ; p=0,000$ ) duygusal yeme puanlarının daha yüksek olduğu bulunmuştur (Tablo 3). 
Tablo 2. Depresyon tanılı hastaların sosyo demografik özelliklerinin duygusal yeme ölçeği puan ortalamaları ile karşılaştırılması.

\begin{tabular}{|c|c|c|c|c|}
\hline $\begin{array}{l}\text { Katılımcıların } \\
\text { Sosyo Demografik } \\
\text { Özellikleri }\end{array}$ & $\mathbf{n}$ & $\%$ & Ort \pm SS & $\begin{array}{c}\text { MWU } / \mathbf{K W} / \mathbf{r} \\
\mathbf{p}\end{array}$ \\
\hline Yaş (ort \pm ss) & 240 & - & $27,52 \pm 12,28$ & $\begin{array}{l}\mathrm{r}=-0,225 \\
p=\mathbf{0 , 0 0 0}\end{array}$ \\
\hline Cinsiyet & & & & \\
\hline $\begin{array}{l}\text { Kadın } \\
\text { Erkek }\end{array}$ & $\begin{array}{l}130 \\
110 \\
\end{array}$ & $\begin{array}{l}54,2 \\
45,8 \\
\end{array}$ & $\begin{array}{l}13,76 \pm 6,73 \\
10,85 \pm 5,66 \\
\end{array}$ & $\begin{array}{c}\text { MWU }=5434,500 \\
p=\mathbf{0 , 0 0 1}\end{array}$ \\
\hline Medeni durum & & & & \\
\hline $\begin{array}{l}\text { Bekar } \\
\text { Evli } \\
\text { Dul/Boşanmış/Ayrı yaşıyor }\end{array}$ & $\begin{array}{c}186 \\
46 \\
8 \\
\end{array}$ & $\begin{array}{c}77,5 \\
19,2 \\
3,3 \\
\end{array}$ & $\begin{array}{l}13,02 \pm 6,54 \\
10,00 \pm 5,29 \\
12,62 \pm 6,90 \\
\end{array}$ & $\begin{array}{c}\mathrm{KW}=8,459 \\
p=\mathbf{0 , 0 1 5}\end{array}$ \\
\hline Ĕgitim düzeyi & & & & \\
\hline $\begin{array}{l}\text { Okuryazar değil } \\
\text { Okuryazar } \\
\text { İlköğretim } \\
\text { Lise } \\
\text { Üniversite } \\
\end{array}$ & $\begin{array}{c}2 \\
12 \\
13 \\
125 \\
88 \\
\end{array}$ & $\begin{array}{r}0,8 \\
5,0 \\
5,4 \\
52,1 \\
36,6 \\
\end{array}$ & $\begin{array}{c}, 00 \pm 2,82 \\
10,16 \pm 3,06 \\
9,76 \pm 6,02 \\
13,59 \pm 6,76 \\
11,50 \pm 0,70 \\
\end{array}$ & $\begin{array}{c}\mathrm{KW}=7,863 \\
p=0,097\end{array}$ \\
\hline Aile Durumu & & & & \\
\hline $\begin{array}{l}\text { Çekirdek aile } \\
\text { Geniş aile }\end{array}$ & $\begin{array}{c}203 \\
37 \\
\end{array}$ & $\begin{array}{l}84,6 \\
15,4 \\
\end{array}$ & $\begin{array}{l}12,33 \pm 6,38 \\
12,91 \pm 6,69 \\
\end{array}$ & $\begin{array}{c}\text { MWU }=3618,500 \\
p=0,724\end{array}$ \\
\hline Evin kime ait olduğu & & & & \\
\hline $\begin{array}{l}\text { Kendi evi } \\
\text { Kira } \\
\text { Lojman } \\
\text { Diğer } \\
\end{array}$ & $\begin{array}{c}165 \\
73 \\
1 \\
1\end{array}$ & $\begin{array}{c}68,8 \\
30,4 \\
0,4 \\
0,4\end{array}$ & $\begin{array}{l}11,92 \pm 602 \\
13,61 \pm 7,20 \\
10,00 \pm 0,00 \\
11,00 \pm 0,00\end{array}$ & $\begin{array}{c}\mathrm{KW}=2,648 \\
p=0,449\end{array}$ \\
\hline $\begin{array}{c}\text { Sosyo-ekonomik düzey } \\
\text { Gelir giderden az } \\
\text { Gelir gidere denk } \\
\text { Gelir giderden fazla } \\
\end{array}$ & $\begin{array}{c}79 \\
136 \\
25 \\
\end{array}$ & $\begin{array}{l}32,9 \\
56,7 \\
10,4 \\
\end{array}$ & $\begin{array}{l}12,64 \pm 7,49 \\
12,55 \pm 5,95 \\
11,08 \pm 5,18 \\
\end{array}$ & $\begin{array}{c}\mathrm{KW}=1,387 \\
p=0,500\end{array}$ \\
\hline $\begin{array}{l}\text { Çalışabilirlik durumu } \\
\text { Düzenli çalışıyor } \\
\text { Düzensiz çalışıyor } \\
\text { Çalışmıyor } \\
\text { Emekli } \\
\end{array}$ & $\begin{array}{c}39 \\
37 \\
159 \\
5\end{array}$ & $\begin{array}{c}16,3 \\
15,4 \\
66,3 \\
2,1\end{array}$ & $\begin{array}{c}12,20 \pm 6,00 \\
12,43 \pm 6,37 \\
12,64 \pm 6,56 \\
7,20 \pm 4,32 \\
\end{array}$ & $\begin{array}{c}\mathrm{KW}=4,014 \\
p=0,260\end{array}$ \\
\hline
\end{tabular}

r: Spearman Korelasyon Analizi, MWU: Mann Whitney U testi, KW: Kruskal Wallis Varyans Analizi.

Tablo 3. Depresyon tanılı hastaların bazı klinik özelliklerinin duygusal yeme ölçeği puan ortalamaları ile karşılaştırılması.

\begin{tabular}{|c|c|c|c|c|}
\hline Katılımcıların Bazı Klinik Özellikleri & $\mathbf{n}$ & $\%$ & Ortalama \pm SS & MWU/KW/p \\
\hline \multicolumn{5}{|l|}{ Sigara kullanma durumu } \\
\hline Hiç kullanmayanlar & 115 & 47,9 & $12,89 \pm 6,21$ & \multirow{3}{*}{$\begin{array}{c}\mathrm{KW}=2,337 \\
p=0,311\end{array}$} \\
\hline Daha önce kullanıp sonradan bırakanlar & 22 & 9,2 & $13,04 \pm 6,93$ & \\
\hline Sürekli kullananlar & 103 & 42,9 & $11,77 \pm 6,53$ & \\
\hline \multicolumn{5}{|l|}{ Alkol kullanma durumu } \\
\hline Hiç içmeyenler & 116 & 48,3 & $12,93 \pm 6,67$ & \multirow{4}{*}{$\begin{array}{c}\mathrm{KW}=3,166 \\
p=0,367\end{array}$} \\
\hline Nadiren içenler (özel günlerde) & 74 & 30,8 & $11,31 \pm 5,90$ & \\
\hline Sürekli içenler & 35 & 14,6 & $13,22 \pm 6,48$ & \\
\hline Daha önce içip, sonradan bırakanlar & 15 & 6,3 & $12,13 \pm 6,62$ & \\
\hline \multicolumn{5}{|l|}{ Özkıyım girişimi } \\
\hline Yok & 128 & 53,3 & $11,30 \pm 6,25$ & \multirow{2}{*}{$\begin{array}{c}\text { MWU }=5563,000 \\
p=\mathbf{0 , 0 0 3}\end{array}$} \\
\hline Var & 112 & 46,7 & $13,71 \pm 6,39$ & \\
\hline \multicolumn{5}{|l|}{ Duygusal yeme gösterdikleri öğünler } \\
\hline \multicolumn{5}{|l|}{ Sabah } \\
\hline Hayır & 202 & 84,2 & $12,59 \pm 6,57$ & \multirow{2}{*}{$\begin{array}{c}\mathrm{MWU}=3519,000 \\
p=0,416\end{array}$} \\
\hline Evet & 38 & 15,8 & $11,52 \pm 5,51$ & \\
\hline \multicolumn{5}{|l|}{ Öğle } \\
\hline Hayır & 192 & 80,0 & $12,41 \pm 6,40$ & \multirow{2}{*}{$\begin{array}{c}\mathrm{MWU}=4590,500 \\
p=0,968\end{array}$} \\
\hline Evet & 48 & 20,0 & $12,50 \pm 6,55$ & \\
\hline
\end{tabular}




\begin{tabular}{|c|c|c|c|c|}
\hline \multicolumn{5}{|l|}{ Akşam } \\
\hline Hayır & 72 & 30,0 & $11,47 \pm 6,08$ & \multirow{2}{*}{$\begin{array}{c}\mathrm{MWU}=5256,000 \\
p=0,108\end{array}$} \\
\hline Evet & 168 & 70,0 & $12,83 \pm 6,53$ & \\
\hline \multicolumn{5}{|r|}{ 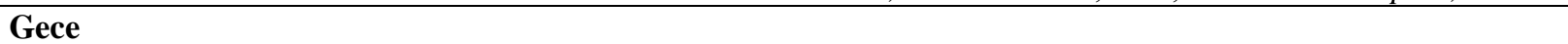 } \\
\hline Hayır & 218 & 90,8 & $12,27 \pm 6,41$ & \multirow{2}{*}{$\begin{array}{c}\text { MWU }=2019,000 \\
p=0,221\end{array}$} \\
\hline Evet & 22 & 9,2 & $14,00 \pm 6,42$ & \\
\hline \multicolumn{5}{|c|}{ Yediklerinin miktarını sınırlamakta sorun yașayanlar } \\
\hline Hayır & 151 & 62,9 & $10,27 \pm 5,61$ & \multirow{2}{*}{$\begin{array}{c}\text { MWU }=3189,500 \\
p=\mathbf{0 , 0 0 0}\end{array}$} \\
\hline Evet & 89 & 37,1 & $16,08 \pm 6,06$ & \\
\hline \multicolumn{5}{|c|}{ Aç olmadığı halde yemek yeme atakları geçirenler } \\
\hline Hayır & 89 & 37,1 & $8,80 \pm 4,92$ & \multirow{2}{*}{$\begin{array}{c}\mathrm{MWU}=3195,500 \\
p=\mathbf{0 , 0 0 0}\end{array}$} \\
\hline Evet & 151 & 62,9 & $14,56 \pm 6,25$ & \\
\hline \multicolumn{5}{|c|}{ Uykusunu ertelemek için gece geç saatlerde yemek yiyenler } \\
\hline Hayır & 151 & 62,9 & $11,16 \pm 5,64$ & \multirow{2}{*}{$\begin{array}{c}\mathrm{MWU}=4854,000 \\
p=\mathbf{0 , 0 0 0}\end{array}$} \\
\hline Evet & 89 & 37,1 & $14,57 \pm 7,09$ & \\
\hline \multicolumn{5}{|c|}{ Doyduktan sonra da yemek yemeye devam edenler } \\
\hline Hayır & 133 & 55,4 & $9,98 \pm 5,13$ & \multirow{2}{*}{$\begin{array}{c}\mathrm{MWU}=3674,000 \\
p=\mathbf{0 , 0 0 0}\end{array}$} \\
\hline Evet & 107 & 44,6 & $15,46 \pm 6,58$ & \\
\hline \multicolumn{5}{|c|}{ Yemek yeme isteği anlık ve dürtüsel olanlar } \\
\hline Hayır & 85 & 35,4 & $10,31 \pm 5,86$ & \multirow{2}{*}{$\begin{array}{c}\mathrm{MWU}=4614,500 \\
p=\mathbf{0 , 0 0 0}\end{array}$} \\
\hline Evet & 155 & 64,6 & $13,58 \pm 6,43$ & \\
\hline \multicolumn{5}{|c|}{ Yemek yerken duygularının onları yönlendirdiğini düşünenler } \\
\hline Hayir & 97 & 40,4 & $10,47 \pm 6,08$ & \multirow{2}{*}{$\begin{array}{c}\mathrm{MWU}=4866,000 \\
p=\mathbf{0 , 0 0 0}\end{array}$} \\
\hline Evet & 143 & 59,6 & $13,75 \pm 6,32$ & \\
\hline \multicolumn{5}{|c|}{ Kilo alıp vermenin ruhsal durum üzerinde etkisi olanlar } \\
\hline Hayır & 71 & 29,6 & $9,38 \pm 5,43$ & \multirow{2}{*}{$\begin{array}{c}\mathrm{MWU}=3591,000 \\
p=\mathbf{0 , 0 0 0}\end{array}$} \\
\hline Evet & 169 & 70,4 & $13,71 \pm 6,38$ & \\
\hline \multicolumn{5}{|c|}{ Duygusal olarak yeme alıșkanlığını fark ettiğinde bir sağlık profesyoneline bașvuranlar } \\
\hline Hayır & 205 & 85,4 & $11,94 \pm 6,28$ & \multirow{2}{*}{$\begin{array}{c}\text { MWU }=2519,500 \\
p=\mathbf{0 , 0 0 5}\end{array}$} \\
\hline Evet & 35 & 14,6 & $15,28 \pm 6,55$ & \\
\hline \multicolumn{5}{|c|}{ Bazı yiyecekleri gizli gizli yiyenler } \\
\hline Hayır & 182 & 75,8 & $10,73 \pm 5,44$ & \multirow{2}{*}{$\begin{array}{c}\text { MWU }=2155,500 \\
p=\mathbf{0 , 0 0 0}\end{array}$} \\
\hline Evet & 58 & 24,2 & $17,74 \pm 6,38$ & \\
\hline \multicolumn{5}{|c|}{ Öğün atlama } \\
\hline Hayır & 41 & 17,1 & $13,24 \pm 6,93$ & \multirow{3}{*}{$\begin{array}{c}\mathrm{KW}=2,320 \\
p=0,314\end{array}$} \\
\hline Evet & 97 & 40,4 & $11,63 \pm 5,93$ & \\
\hline Bazen & 102 & 42,5 & $12,85 \pm 6,63$ & \\
\hline \multicolumn{5}{|c|}{ Atlanılan öğün } \\
\hline Sabah & 85 & 35,4 & $12,07 \pm 6,30$ & \multirow{3}{*}{$\begin{array}{c}\mathrm{KW}=2,231 \\
p=0,328\end{array}$} \\
\hline Öğlen & 111 & 46,3 & $12,64 \pm 6,30$ & \\
\hline Akşam & 7 & 2,9 & $8,85 \pm 4,29$ & \\
\hline
\end{tabular}

MWU: Mann Whitney U testi, KW: Kruskal Wallis Varyans Analizi.

Depresyon tanılı hastaların duygusal yeme ölçeği, gözden geçirilmiş sosyal sorun çözme ölçeği ve stresle başa çıkma tarzları ölçeği toplam puanları ile alt ölçek puan değerleri Tablo 4'de verilmiştir.

Depresyon tanilı hastalarda duygusal yeme ölçeği toplam puan ortalaması ile gözden geçirilmiş sosyal sorun çözme ölçeği toplam puan ortalaması arasında negatif yönde zayıf düzeyde anlamlı bir ilişki $(\mathrm{r}=-0,342$; $p=0,000)$, gözden geçirilmiş sosyal sorun çözme ölçeğinin alt ölçekleri olan negatif sorun yönelimi $(\mathrm{r}=0,361 ; p=0,000)$, dürtüsel dikkatsiz sorun çözme tarzı ( $\mathrm{r}=0,316$; $p=0,000)$ ve kaçıngan sorun çözme tarzı arasında pozitif yönde zayıf düzeyde anlamlı iliş̧i bulunmuştur $(\mathrm{r}=0,298 ; p=0,000) \quad$ (Tablo $5)$.

Depresyon tanılı hastalarda duygusal yeme ölçeği toplam puan ortalaması ile stresle başa çıkma tarzları ölçeğinin toplam puan ortalaması arasında pozitif yönde çok zayıf düzeyde anlamlı bir ilişki vardır ( $\mathrm{r}=0,149$; $p=0,021)$. Duygusal yeme ölçeği toplam puan ortalaması ile stresle başa çıkma tarzları ölçeğinin alt ölçekleri olan kendine güvenli yaklaşım ile negatif yönde zayıf $(\mathrm{r}=-0,272$; $p=0,000$ ), iyimser yaklaşım ile negatif yönde çok zayıf $(\mathrm{r}=-0,249 ; \quad p=0,000), \quad$ çaresiz yaklaşım ve $(\mathrm{r}=0,427 ; p=0,000)$ boyun eğici 
yaklaşım puan ortalaması arasında ise pozitif yönde zayıf düzeyde anlamlı bir ilișki vardır $(\mathrm{r}=0,385 ; p=0,000)$. Duygusal yeme ölçeği toplam puan ortalaması ile stresle başa çıkma tarzları ölçeğinin alt ölçeği olan sosyal destek arayan yaklaşım toplam puan ortalaması arasında anlamlı bir ilişki bulunamamıştır $(\mathrm{r}=0,105 ; p=0,104)$ (Tablo 6).

Tablo 4. Depresyon tanılı hastaların duygusal yeme ölçeği, gözden geçirilmiş sosyal sorun çözme ölçeği ve stresle başa çıkma tarzları ölçeği toplam puanları ile alt ölçek puan değerleri.

\begin{tabular}{|c|c|c|c|c|c|c|}
\hline Ölçekler & $\mathbf{n}$ & $\%$ & Min & Max & Range & $\overline{\mathbf{X}} \pm \mathbf{S S}$ \\
\hline DYÖT* & 240 & 100 & 1 & 30 & 29 & $12,42 \pm 6,42$ \\
\hline Tr-SSÇE-GT** & 240 & 100 & 14 & 95 & 81 & $59,0 \pm 15,75$ \\
\hline $\begin{array}{l}\text { Tr-SSÇE-G } \\
\text { Alt ölçeği } \\
\text { OSY** }\end{array}$ & 240 & 100 & 0 & 20 & 20 & $11,8 \pm 4,59$ \\
\hline $\begin{array}{l}\text { Tr-SSÇE-G } \\
\text { Alt ölçeği } \\
\text { NSY** }\end{array}$ & 240 & 100 & 0 & 20 & 20 & $9,02 \pm 4,94$ \\
\hline $\begin{array}{l}\text { Tr-SSÇE-G } \\
\text { Alt ölçeği } \\
\text { ASÇT*** }^{* *}\end{array}$ & 240 & 100 & 0 & 20 & 20 & $11,54 \pm 4,30$ \\
\hline $\begin{array}{l}\text { Tr-SSÇE-G } \\
\text { Alt ölçeği } \\
\text { DDSÇT** }\end{array}$ & 240 & 100 & 0 & 20 & 20 & $8,06 \pm 4,02$ \\
\hline $\begin{array}{l}\text { Tr-SSÇE-G } \\
\text { Alt ölçeği } \\
\text { KSÇT** }\end{array}$ & 240 & 100 & 0 & 20 & 20 & $7,25 \pm 4,87$ \\
\hline SBÇTÖT*** & 240 & 100 & 13 & 73 & 60 & $44,78 \pm 8,79$ \\
\hline $\begin{array}{l}\text { SBÇTÖ } \\
\text { Alt ölçeği } \\
\text { KGY*** }\end{array}$ & 240 & 98,3 & 0 & 21 & 21 & $12,59 \pm 4,70$ \\
\hline $\begin{array}{l}\text { SBÇTÖ } \\
\text { Alt ölçeği } \\
\text { IYY*** }\end{array}$ & 240 & 100 & 0 & 15 & 15 & $8,03 \pm 3,43$ \\
\hline $\begin{array}{l}\text { SBÇTÖ } \\
\text { Alt ölçeği } \\
\text { ÇY*** }\end{array}$ & 240 & 100 & 0 & 24 & 24 & $11,26 \pm 4,82$ \\
\hline $\begin{array}{l}\text { SBÇTÖ } \\
\text { Alt ölçeği } \\
\text { BEY*** } \\
\end{array}$ & 240 & 100 & 0 & 15 & 15 & $6,35 \pm 3,42$ \\
\hline $\begin{array}{l}\text { SBÇTÖ } \\
\text { Alt ölçeği } \\
\text { SDAY*** }\end{array}$ & 240 & 100 & 0 & 12 & 12 & $6,63 \pm 2,04$ \\
\hline
\end{tabular}

*DYÖT: Duygusal Yeme Ölçeği Toplam, ** Tr-SSÇE-GT: Gözden Geçirilmiş Sosyal Sorun Çözme Ölçeği Toplam, **OSY: Olumlu Sorun Yönelimi, **NSY: Negatif Sorun Yönelimi, **ASÇT: Akılcı Sorun Çözme Tarzı, **DDSÇT: Dürtüsel-Dikkatsiz Sorun Çözme Tarzı, **KSÇT: Kaçıngan Sorun Çözme Tarzı, ***SBÇTÖT: Stresle Başa Çıkma Tarzları Ölçeği Toplam, ***KGY: Kendine Güvenli Yaklaşım, ***iYY: İyimser Yaklaşım, ***BEY: Boyun Eğici Yaklaşım, ${ }^{* * * C ̧ Y: ~ C ̧ a r e s i z ~ Y a k l a s ̧ ı m, ~}{ }^{* * * S D A Y: ~ S o s y a l ~ D e s t e k ~ A r a y a n ~ Y a k l a s ̧ ı m ~}$

Tablo 5. Depresyon tanılı hastalarda duygusal yeme ölçeği toplam puan ortalaması ile gözden geçirilmiş sosyal sorun çözme ölçeği toplam puanı ve alt ölçek puanları arasındaki ilişki.

\begin{tabular}{lllllll}
\hline Ölçekler & $\begin{array}{l}\text { Tr-SSÇE- } \\
\text { GT }\end{array}$ & $\begin{array}{l}\text { Tr-SSÇE-G } \\
\text { Alt ölçeği } \\
\text { OSY }\end{array}$ & $\begin{array}{l}\text { Tr-SSÇE-G } \\
\text { Alt ölç̧eği } \\
\text { NSY }\end{array}$ & $\begin{array}{l}\text { Tr-SSÇE-G } \\
\text { Alt ölçeği } \\
\text { ASÇT }\end{array}$ & $\begin{array}{l}\text { Tr-SSÇE-G } \\
\text { Alt ölçeği } \\
\text { DDSÇT }\end{array}$ & $\begin{array}{l}\text { Tr-SSÇE-G } \\
\text { Alt ölçeği } \\
\text { KSÇT }\end{array}$ \\
\hline DYÖT & $-0,342$ & $-0,112$ & 0,361 & $-0,086$ & 0,316 & 0,298 \\
& $\mathbf{0 , 0 0 0 ^ { * }}$ & 0,084 & $\mathbf{0 , 0 0 0 ^ { * }}$ & 0,185 & $\mathbf{0 , 0 0 0 ^ { * }}$ & $\mathbf{0 , 0 0 0 ^ { * }}$ \\
\hline
\end{tabular}

* p =0,000, Tr-SSÇE-GT: Gözden geçirilmiş sosyal sorun çözme ölçeği toplam, OSY: Olumlu sorun yönelimi, NSY: Negatif sorun yönelimi, ASÇT: Akılcı sorun çözme tarzı, DDSÇT: Dürtüsel-dikkatsiz sorun çözme tarzı, KSÇT: Kaçıngan sorun çözme tarzı

Tablo 6. Depresyon tanılı hastalarda duygusal yeme ölçeği toplam puan ortalaması ile stresle başa çıkma tarzları ölçeği toplam ve alt ölçek puan ortalamaları arasındaki ilişki.

\begin{tabular}{lllllll}
\hline Ölçekler & SBÇTÖT & $\begin{array}{l}\text { SBÇTÖ } \\
\text { Alt ölçeği }\end{array}$ & $\begin{array}{l}\text { SBÇTÖ } \\
\text { Alt ölçeği } \\
\text { KGY }\end{array}$ & $\begin{array}{l}\text { SBÇTÖ } \\
\text { Alt ölçeği }\end{array}$ & $\begin{array}{l}\text { SBÇTÖ } \\
\text { Alt ölçeği } \\
\text { BEY }\end{array}$ & $\begin{array}{l}\text { SBÇTÖ } \\
\text { Alt ölçeği } \\
\text { SDAY }\end{array}$ \\
\hline DYÖT & 0,149 & $-0,272$ & $-0,249$ & 0,427 & 0,385 & 0,105 \\
& $\mathbf{0 , 0 2 1}^{*}$ & $\mathbf{0 , 0 0 0 * *}$ & $\mathbf{0 , 0 0 0 * *}$ & $\mathbf{0 , 0 0 0 * *}$ & $\mathbf{0 , 0 0 0 ^ { * * }}$ & 0,104 \\
\hline
\end{tabular}


*p<0,05, ** p<0,01, SBÇTÖT: Stresle Başa Çıkma Tarzları Ölçeği Toplam, KGY: Kendine Güvenli Yaklaşım, IY: İyimser Yaklaşım, BEY: Boyun Eğici Yaklaşım, ÇY: Çaresiz Yaklaşım, SDAY: Sosyal Destek Arayan Yaklaşım

\section{Tartışma}

$\mathrm{Bu}$ araştırmada depresyon tanılı hastalarda duygusal yeme ve etkileyen faktörleri belirlemek amaçlanmıştır. Depresyon tanılı hastalarda yaş azaldıkça duygusal yemenin arttığ bulunmuştur. Benzer şekilde Arslantaş ve arkadaşlarının ${ }^{35}$ yapmış olduğu çalışmada da yaş azaldıkça duygusal yemenin arttığ belirtilmiştir. Diğer taraftan yapılan bir çalışmada duygusal yemede yaşın anlamlı yordayıcı bir etken olmadığ 1 bildirilmiştir. ${ }^{36}$ Çalışma bulgusunun nedeninin depresyon tanılı hastaların yaş azaldıkça duygusal yemeyi bir baş etme mekanizması olarak kullanıyor olmalarından kaynaklanmış olabileceği şeklinde yorumlanmıştır ${ }^{37}$

Kadın cinsiyetinde olmanın duygusal yemeyi arttırdığg bulunmuştur. Cinsiyetin duygusal yeme ile ilişkisini araştıran birçok çalışmada da benzer sonuçlara rastlanmaktadır. Cotter ve Kelly ${ }^{38}$ kadınların duygusal yemeye daha yatkın olduğunu ve stres altında yemek yiyip kilo aldıklarını, Thompson ve Romeo ${ }^{39}$ kadinlarda depresyon, stres ve anksiyetenin erkeklere kıyasla aşırı yemeyi etkilediğini, Candan ve Küçük $^{40}$ kadınlarda erkeklere oranla yeme bağımlılığ puanının daha yüksek olduğunu, Herle ve arkadaşları ${ }^{41}$ paylaşılmayan çevresel faktörlerin depresif semptomlar ile birlikte duygusal yeme arasındaki örtüşmeyi kadınlarda açıklarken erkeklerde açıklamadığını, Arslantaş ve arkadaşları ${ }^{35}$ kadın öğrencilerin daha fazla duygusal yeme eğiliminde olduğunu bildirmişlerdir. Diğer taraftan çalışma bulgularımızdan farklı olarak Nguyen-Rodriguez ve $\operatorname{arkadaşlari~}^{42}$ yapmış oldukları çalışmada duygusal yemede cinsiyet farklılığının etken olmadığı ancak algılanan stres ve endişenin, duygusal yemeyi etkilediği; kadınlarda algılanan stres, kaygı, endişe, gerginlik hissinin, erkeklerde ise karışık ruh halinin duygusal yeme ile ilişkili olduğunu saptamışlardır. Aynı şekilde Chamberlin $^{7}$ ile Tariq ve arkadaşları 36 duygusal yemede cinsiyetin istatistiksel olarak anlamlı yordayıcı olmadığını bildirmişlerdir. Son yıllarda yapılan araştırmalar, stresin kadınlarda duygusal yeme için en güçlü tetikleyici olduğunu göstermektedir. ${ }^{17,38,39,43}$ Literatürdeki farklı sonuçların nedeninin duygusal yemeyi değerlendirmek için kullanılan ölçeklerin farklılığından kaynaklanmış olabileceği düşünülmüştür.

Depresyon tanılı hastalarda bekar olmanın duygusal yemeyi arttırdığı bulunmuştur. Çalışma bulgularımızın tersine Arslantaş ve arkadaşları 35 yapmış oldukları çalışmada öğrencilerin odada tek başına kalmamasının duygusal yemeyi arttırdığını bildirmişlerdir. Pek çok çalışmada da çalışma bulgularımıza benzer şekilde yalnızlığın duygusal yemeyi arttırdığı bildirilmektedir. ${ }^{7,9,44}$ Yalnız bireyler yemeyi bir baş etme yöntemi olarak kullaniyor olabilirler. Duygusal yeme davranışı yalnızlık, depresyon, anksiyete gibi duygu değişimlerine karşıllk olarak genellikle normalden daha fazla yemek yemeye neden olan psikolojik yeme çeşidi olarak da tanımlanmıştır. ${ }^{9}$ Duygusal yeme olarak tanımlanan bu yeme davranışı, ruh halinin kontrolü için besin tüketiminin bir sonucudur. ${ }^{6,7}$

Depresyon tanılı hastaların eğitim düzeyinin, aile tipinin, evin kime ait olduğunun, sosyo-ekonomik düzeylerinin ve çalışabilirlik durumlarının duygusal yemelerini etkilemediği bulunmuştur. Arslantaş ve arkadaşlarının ${ }^{35}$ yapmış olduğu çalışmada da öğrencilerin aile gelir düzeyinin duygusal yemelerini etkilemediği bildirilmiştir. Çalışmanın diğer bulguları ile ilgili olarak herhangi bir araştırma bulgusuna rastlanmamıştır. Bunun nedeni olarak duygusal yeme son yıllarda araştırmacıların yeni ilgi alanı olduğu için konu ile ilgili yeterli bilginin alanyazın çalışmalarında birikmemiş olması ile ilgili olabileceği şeklinde düşünülmüştür. Diğer yeme bozukluklarında olduğu gibi duygusal yeme de bir yeme bozukluğu olarak henüz tanımlanmasa da risk gruplarını tanımlamak, etkileyen faktörleri belirlemek ve gerekli müdahale yaklaşımlarını saptamak amacı ile duygusal yeme konusunda da araştırmaların yapılmasına ihtiyaç olduğu düşünülmektedir. 
Araştırmamızda duygusal yeme ile özkıyım girişiminde bulunmuş olma arasında anlamlılık saptanmıştır. Bu sonuç ile ilgili herhangi bir araştırma bulgusuna rastlanmamıştır. Ancak bu sonucun araştırmamızın diğer bulguları ile örtüştüğü düşünülmüştür. Diğer bulgularımızda hastalar sorunlarını olumlu olarak ele aldıklarında ve sorunların çözümüne akıllıca yaklaştıklarında yeme davranışını kullanmaya gerek duymadıkları ve negatif sorun yönelimleri, dürtüsel dikkatsiz ve kaçıngan sorun çözme tarzları arttıkça duygusal yemelerinin arttığ şeklindeydi. Ayrıca hastaların stresle baş etmek için kendine güvenli yaklaşım ve iyimser yaklaşımı kullandıklarında da duygusal yemelerinin azaldığı da bir başka bulgumuzdu.

Depresyon tanılı hastaların bazı klinik özellikleri ile duygusal yeme ölçeği puan ortalamaları karşılaştırıldığında yediklerinin miktarını sınırlamakta sorun yaşamanın, aç olmadığı halde yemek yeme atakları geçirmenin, uykusunu ertelemek için gece geç saatlerde yemek yemenin, doyduktan sonra da yemek yemeye devam etmenin, yemek yeme isteğinin anlık ve dürtüsel olmasının, yemek yerken duygularının onları yönlendirdiğini düşünmenin, kilo alıp vermenin ruhsal durumları üzerinde etkisinin olmasının, duygusal olarak yeme alışkanlığını fark ettiğinde bir sağlik profesyoneline başvurmanın, bazı yiyecekleri gizli gizli yiyenlerin duygusal yeme puanlarının daha yüksek olduğu bulunmuştur.

Arslantaş ve arkadaşlarının $^{35}$ yapmış olduğu çalışmada da öğrencilerin yediklerinin miktarını sınırlamakta sorun yaşamalarının, aç olmadıkları halde yemek yeme atağı geçirmelerinin, uykuyu ertelemek için gece geç saatlerde yemek yemelerinin, doyduktan sonra yemek yemeye devam etmelerinin, anlık ve dürtüsel yemek yemelerinin, yemek yerken duygularının kendisini yönlendirmesinin, kilo alıp vermenin ruhsal durumuna etkisinin olmasının, duygusal yeme nedeni ile sağlık profesyoneline başvurmasının ve gizli gizli yemek yemelerinin duygusal yemelerini etkilediğini bulgulamışlardır. Konttinen ve arkadaşları 45 yedi saat veya daha az uyuyanlarda duygusal yemenin daha fazla olduğunu ve bununda daha yüksek beden kitle indeksi ve bel çevresi ile ilişkili olduğunu bildirmişlerdir. AlMusharaf 18 pandemi sırasında genç Suudi kadınlar arasında duygusal yemeyi araştırdığı çalışmasında duygusal yemenin daha yüksek stres, daha kötü ve az uyku ile ve daha az fiziksel aktiviteyle ilişkili olduğunu bildirmiştir.

Çalışmamızda depresyon tanılı hastalarda duygusal yeme ile olumlu sorun yönelimi ve akılcı sorun çözme tarzı arasında bir ilişki bulunamazken, negatif sorun yönelimi, dürtüsel dikkatsiz sorun çözme tarzı ve kaçıngan sorun çözme tarzı arasında pozitif yönde anlamlı bir ilişki bulunmuştur. $\mathrm{Bu}$ bulgular şu şekilde yorumlanabilir. Hastalar sorunlarını olumlu olarak ele aldıklarında ve sorunların çözümüne akıllıca yaklaştıklarında yeme davranışını kullanmaya gerek duymamaktadırlar. Depresyon hastalarının negatif sorun yönelimleri, dürtüsel dikkatsiz ve kaçıngan sorun çözme tarzları arttıkça ise duygusal yemeleri artmaktadir. $\mathrm{Bu}$ sonuç diğer çalışma bulgumuz olan hastaların stresle baş etmek için kendine güvenli yaklaşım ve iyimser yaklaşımı kullandıklarında duygusal yemenin azalması sonucu ile benzerlik göstermektedir. Benzer şekilde ergenlerle yapılan bir çalışmada da algılanan stresin daha yüksek seviyelerinde, kaçıngan başa çıkma tarzının depresif duygusal yeme eğilimini arttırdığı bildirilmiştir. ${ }^{46}$

Depresyon sadece yetişkinlik dönemi ile sınırlı bir kavram değildir. Dolayısıyla çocukluk dönemi yetişkinlik dönemindeki besin davranışlarını etkileyen en önemli basamaklardan biridir. Depresyon tanılı hastalarda çocukluk döneminde yaşanan travmalar yetişkinlik dönemindeki depresyon ve duygusal yeme davranışı ile ilişkili olabilmektedir. Yapılan bir çalışmada daha yüksek düzeyde duygusal yeme, vücut kitle indeksi, gelir düzeyi, çocukluk ve yetişkinlik döneminde travmaya maruz kalma, depresif ve Travma Sonrası Stres Bozukluğu (TSSB) belirtileri, olumsuz duygulanım ve duygu düzenleme bozukluğu ile ilişkilendirilmiştir. Ayrıca çocukluktaki duygusal istismarın yetişkinlikteki duygusal yeme ile ilişkili olduğu bildirilmiştir. ${ }^{47}$ Yapılan çalışmalarda 
da depresyon, TSSB ve çocukluktaki kötü muamelenin obezite ile yüksek oranda komorbidite içerisinde olduğu belirtilmekte olup $^{48-51}$ bununda artmış duygusal yeme ile sonuçlanabileceği bildirilmektedir. ${ }^{52}$ TSSB ile duygusal yeme arasındaki ilişkiyi araştırmak amacı ile yapılan bir çalışmada TSSB olan katılımcıların yaşam boyu psikiyatrik öyküsü olmayan kontrol grubu katılımcılarından daha fazla duygusal yeme sergiledikleri ve duygusal yemenin TSSB semptom şiddeti arttıkça arttığı bildirilmiştir. ${ }^{52}$

Khosravi $^{53}$ borderline kişilik bozukluğu olan hastalarda yeme bozukluklarının yaygınlığını ve psikopatolojisini araştırmak amacı ile yaptı̆̆ 1 çalışmada; borderline kişilik bozukluğu olan hastalarda beslenme ve yeme bozuklukları yaygınlığının \%65,4 olduğunu bildirmiştir. Aynı çalışmada aleksitimi ile yeme bozukluğu davranışları arasındaki ilişkide kaygı ve depresyonun aracılık rolü oynadığını da bulgulanmıştır. ${ }^{53}$

Bilişsel davranışçı görüşlere göre, bireyin kendisi hakkında olumsuz düşünceler üretmesine erken yaşlarda yaşanan travmatik ya da olumsuz deneyimler yol açmaktadır. Bireyin kendisi hakkındaki olumsuz inanışları fiziki görünüşü, kilosu ya da yeme tutumuyla ilgili bir yorumda bulunulması halinde kendini gösterebilir ve otomatik olarak bunlarla ilgili olumsuz düşünce ve duygusal yanıtların oluşmasına sebep olabilir. Kişiye sıkıntı veren bu duygusal yanıtlar sonucunda yeme davranışı ile ilgili hem olumlu hem de olumsuz düşünceler ortaya çıkabilir. Kişi, duygusal olarak yaşadığı sıkıntıdan kurtulmak amacıyla yemek yerse, göstermiş olduğu bu tutum sonrasinda "kendime yeme konusunda engel olamıyorum" şeklinde yemek yemenin kontrol edilemeyeceğine dair yeni düşünceler üretebilir. $^{54}$

Duygularin yeme tutumlarina hangi yönlerden etki ettiğine dair çeşitli görüşler mevcuttur. Örneğin, olumsuz duygu durumları ile aşırı besin alımı arasında ne derece ilişki olduğunu araştıran bir çalışmada mutluluk haline kıyasla üzüntü durumunun besin alımını daha çok etkilediği saptanmıştır. $^{55}$ Braden ve arkadaşlari $^{56}$ depresif, endişeli, sıkılmış veya mutluyken yemek yemede duygusal yeme türleri ve psikolojik-fiziksel sağlıkla ilişkisini araştırmak amacı ile yaptıkları çalışmada depresyona tepki olarak yemek yemenin, psikolojik iyi oluş, yeme bozukluğu belirtileri ve duygu düzenleme güçlükleri ile en yakından ilişkili duygusal yeme türü olduğunu bulgulamışlardır. ${ }^{56}$

Soukup ve $\operatorname{arkadaşlar1~}^{57}$ yeme bozukluğu olan hastalarda beslenme, stresle baş etme tarzı ve problem çözme becerilerini araştırmışlardır. $\mathrm{Bu}$ araştırmanın sonucuna göre bulimik hastalar, yeme bozukluğu olan diğer hastalarla karşılaştırıldığında daha fazla olumsuz yaşam deneyimine ve baskı altında olma duygusuna sahiptir. Anoreksiklerde ise diğer gruplara kıyasla daha yüksek seviyede anksiyete ve depresyon gözlemlenmiştir. Her iki grupta da (bulimik ve anoreksiklerde) yüksek seviyede anksiyete, problem çözme yeteneklerinde kendine güven eksikliği, problemlerle yüzleşmekten kaçınma eğilimi, kişisel sorunlarını paylaşmakta isteksizlik ve tükenmişlik hissi gözlemlenmiştir. Yapılan bir çalışmada da negatif duygunun seviyesi kontrol edilirken hem duygu odaklı başa çıkma hem de dikkati başka yöne çekme ile duygusal yeme arasında pozitif ilişki olduğu bildirilmiştir. ${ }^{58}$ Svaldi ve arkadaşları ${ }^{59}$ yapmış oldukları çalışmada yeme bozukluğu olan kadınlar ile sağlıklı kadınlar arasında kişiler arası ilişkilerde etkili problem çözme becerilerini karşılaştırmışlardır. Araştırma sonucunda aşırı yeme bozukluğu olan kadın grubunda üretilen çözümler, sağlıklı gruba kıyasla daha az etkili ve daha az spesifik olarak bulunmuştur. Ayrıca, kişilerarası problem çözme etkinliğinin azalması, aşırı yeme sıklığı ile ilişkili bulunmuştur. Alanyazın çalışma bulguları ile çalışma bulgularımız benzerlik göstermiştir.

Çalışmamızda hastaların stresle başa çıkmak için duygusal yeme davranışında bulundukları, stresle başa çıkmak için kullanılan kendine güvenli yaklaşım ve iyimser yaklaşım azaldıkça, çaresiz yaklaşım ve boyun eğici yaklaşım arttıkça da duygusal yemenin arttığı bulunmuştur. Duygusal yeme, daha çok stres durumuna yanıt oluşturma tutumu olarak düşünülmektedir. Özellikle sel, deprem gibi doğal felaketler sonrası strese yüksek maruziyet olduğu görülmüş ve bunun 
da yeme davranışını etkilediği saptanmıştır. Ortalama iki yılı kapsayan 105 orta yaşta kadının dahil olduğu kesitsel bir araştırmada, kadınların deprem öncesi ve sonrası yeme tutumları incelenmiş ve yeme tutumu ile yüksek strese maruz kalma durumu ilişkili bulunmuştur. Depreme bağlı olarak ortaya çıkan yüksek stres seviyesi, sağlıklı yeme davranışlarında (kahvaltı yapma, sebze, meyve tüketme vb. gibi) azalmaya neden olmuştur. $^{60}$ Geliebter ve Aversa ${ }^{61}$ şişman bireylerde negatif duyguların zayıf bireylerde ise pozitif duyguların var olması halinde duygusal yemenin arttığını tespit etmişlerdir. De Young ve arkadaşları ${ }^{62}$ pozitif duygu durumlarının tıkınırcasına yeme ataklarını azalttığını, negatif duygu durumlarının ise tıkınırcasına yeme ataklarını arttırdığını bildirmişlerdir. Tikınırcasına yeme bozukluğunda klinik ve sosyodemografik özellikleri araştıran bir çalışmada, göç etmenin tıkınırca yeme alışkanlığına neden olduğu ileri sürülmüştür. ${ }^{63}$ Bulimia nervozada tıkınırcasına yeme tutumlarıyla benzer şekilde kişideki stres ve negatif duygu durumunun yeme davranışı ile azaltılacağı düşüncesi ön plandadır. Anoreksiya nervozadaki duygu durumu ise kişinin yeme davranışındaki kontrol mekanizmasını kaybetme korkusu ile ilişkilendirilmektedir. ${ }^{64}$ Cecchetto ve arkadaşları ${ }^{15}$ stres ile aşırı yeme arasında ilişki olduğunu bildirmişlerdir. Penaforte ve arkadaşları $^{65}$ stresi yüksek olan öğrencilerin düşük seviyeli olanlara kıyasla, duygusal yeme ve kontrolsüz yeme davranışının daha yüksek olduğunu ve bu durumda da hazır yemek türü atıştırmalıkların ve sandviçlerin tüketim sıklığının daha yüksek olduğunu bulgulamışlardır. Düzenli yeme alışkanlığına sahip olmayan 345 genç birey arasında yapılan bir araştırmada stresin, kişilerdeki açlik ve tokluk sinyallerine cevap oluşturma yeteneğini azaltarak, bu kişilerin yüksek oranda duygusal yeme davranış1 göstermelerine neden olduğu tespit edilmiştir. ${ }^{66}$

"Maskeleme hipotezi" stresin duygusal
yeme üzerine etkisinin tartışıldığı bir
yaklaşımdır. Bu hipotez negatif duygulara
karş1lı olarak yemenin bu duyguları
gizleyebileceğini ileri sürmektedir. Çünkü

aşırı yiyecek tüketmenin kişide oluşturduğu hoşnutsuzlukla mücadele edebilmek, kişi için daha ciddi bir sorun kaynağı olan stresle uğraşmaya göre daha kolaydır. ${ }^{67}$ Temel ve arkadaşlarının $^{68}$ üniversite öğrencileri üzerinde yapmış oldukları bir çalışmada; yüksek düzeyde depresif belirtiler gösteren öğrencilerin sosyal destek arayan yaklaşım, çaresiz yaklaşım ve boyun eğici yaklaşımı, düşük düzeyde depresif belirtiler gösteren ögrencilerin ise kendine güvenli yaklaşım ve iyimser yaklaşımı daha çok kullandığını tespit etmişlerdir.

Olumsuz duygulara tepki olarak yemek yemenin depresyon ve obezite arasında aracı olduğu bildirilmektedir. ${ }^{16}$ Van Strien ve arkadaşları $^{69}$ yapmış oldukları çalışmada; depresif belirtilerin daha yüksek duygusal yeme ile ilişkili olduğunu ve duygusal yemenin depresyondan bağımsız olarak Beden Kitle İndeksinde de artışlara neden olduğunu bildirmişlerdir. Yapılan çalışmalarda erkek ve kadınlar arasında duygusal yeme ve depresif semptomlarm pozitif ilişkili olduğu ve her ikisinin de daha yüksek beden kitle indeksi ile ilişkili olduğu bildirilmektedir. ${ }^{47,}{ }^{70}$ Yine Y1lmaz ve Köse ${ }^{71}$ de üniversite öğrencilerinde yapmış oldukları çalışmada duygusal iştah ve depresyon puanlarının obez grupta daha yüksek olduğunu bulmuşlardır. Paans ve arkadaşları ${ }^{19}$ dört Avrupa ülkesinde depresyon ve yeme tarzları arasındaki ilişkiyi araştırmak amacı ile yaptıkları çalışmalarında depresyon öyküsü ve şiddetinin daha duygusal ve kontrolsüz yeme ve daha az bilişsel kısıtlı yeme ile ilişkili olduğunu bildirmişlerdir.

Aoun ve arkadaşlarının $^{72}$ yapmış olduğu çalışmada da kadınlarda artan BKİ, kontrolsüz yeme ve duygusal yeme ile ilişkilendirilirken, erkeklerde BKİ sadece duygusal yeme ile ilişkilendirilmiştir. Erkeklerde BKİ ile dürtüsellik arasında bir ilişski bulunmazken, kadınlarda bu ilişkinin olduğu bildirilmiştir. Depresyon puanları daha yüksek olan kadınlarda bilişsel kısıtlama daha düşükken, erkekler arasında daha yüksek anksiyete puanları kontrol edilemeyen yeme ile ilişkilendirilmiştir. Çalışma sonucunda BKİ, duygusal yeme puanları, dürtüsellik ve 
anksiyete/depresyon puanları arasında önemli korelasyonlar bulunduğu belirtilmiştir. ${ }^{72}$

Kaplan' $1 n^{73}$ obezite teorisine göre obezite sorunu olan bireyler gergin ve sikıntıli bir durumla karşı karşıya kaldıklarında bu durum sonucunda ortaya çıkan anksiyeteyi azaltmak için aşırı besin tüketme isteği duyarlar. Obez bireyler fizyolojik açlığa cevap olarak yedikleri gibi anksiyeteye cevap olarak da yemek yeme davranışı gösterirler. Bizim yapmış olduğumuz çalışmada da stresle baş etmek için boyun eğici yaklaşım ve çaresiz yaklaşım kullanıldığında duygusal yeme artmakta, kendine güvenli yaklaşım ve iyimser yaklaşım kullanıldığında ise duygusal yeme azalmaktadır. Sonuçlarımız alanyazın çalışma sonuçları ile benzerlik göstermektedir. ${ }^{10-12,20,55,62,67,73}$

$\mathrm{Bu}$ sonuçlar depresif bilişlerle de açıklanabilir. Boyun eğici yaklaşım ve çaresiz yaklaşım, depresyonda görülen çaresizlik sonucunda gelişen maladaptif davranışlar ile de ilişkilidir. $\mathrm{Bu}$ nedenle bu durum bir kısır döngü olarakta açıklanabilir.

\section{Araştırmanın sınırlılıkları}

$\mathrm{Bu}$ araştırmanın bazı sınırlılıkları bulunmaktadır. $\mathrm{Bu}$ sinırlılıklardan ilki araştırmada yalnızca depresyon tanılı hastalarda duygusal yemeyi etkileyen faktörlerin araştırılmış olmasıdır. Depresyon tanısı alan hastalarda obesite, TSSB, çocukluk travması, kişilik bozukluğu tipleri ve BKİ ile duygusal yeme ilişkisine bakılmamış olması ise araştırmanın başka bir sınırlılığıdır. Araştırma sonuçları araştırmada kullanılan ölçüm araçları ile sınırlıdır.

\section{Sonuç}

Çalışmaya katılan hastaların çoğunluğu kadınlardan ve bekarlardan oluşmaktadır. Hastaların yaklaşık yarısının özkıyım girişiminde bulunduğu tespit edilmiştir. Depresyon tanılı hastaların yaşının azalmasının, kadın ve bekar olmasının duygusal yemeyi arttırdığı bulunmuştur. Hastaların özkıyım girişiminde bulunmuş olmasının, yediklerinin miktarını sınırlamakta sorun yaşamasının, aç olmadığ 1 halde yemek yeme atakları geçirmesinin, uykusunu ertelemek için gece geç saatlerde yemek yemesinin, doyduktan sonra da yemek yemeye devam etmesinin, yemek yeme isteğinin anlık ve dürtüsel olmasının, yemek yerken duygularının kendisini yönlendirdiğini düşünmesinin, kilo alıp vermenin ruhsal durumu üzerinde etkisinin olmasının, duygusal olarak yeme alışkanlığını fark ettiğinde bir sağlik profesyoneline başvurmasının, bazı yiyecekleri gizli gizli yiyenlerin duygusal yeme puanlarının daha yüksek olduğu bulunmuştur.

Hastaların sorunlarını olumlu olarak ele aldıklarında ve sorunların çözümüne akıllıca yaklaştıklarında yeme davranışını kullanmaya gerek duymadikları, negatif sorun yönelimleri, dürtüsel dikkatsiz ve kaçıngan sorun çözme tarzları arttıkça ise duygusal yemelerinin arttığı belirlenmiştir. Hastaların stresle başa çıkmak için duygusal yeme davranışında bulundukları, stresle başa çıkmak için kullanılan kendine güvenli yaklaşım ve iyimser yaklaşım azaldıkça, çaresiz yaklaşım ve boyun eğici yaklaşım arttıkça da duygusal yemenin arttığı bulunmuştur.

Bireylerin depresyon sirasında fazla yemek yemeleri kilo almalarına ve beraberinde metabolik sendrom riski taşımalarına neden olabilir. $\mathrm{Bu}$ da ilerleyen süreçlerde diabet, hipertansiyon, kalp damar hastalıkları ve diğer birçok fiziksel sağlık problemlerinin oluşmasına zemin hazırlayabilir. Bu nedenle depresyon tanılı hastalarda yemek yeme ihtiyacının daha çok hangi nedenlere bağlı olarak ortaya çıktığını belirlemek ve bu sonuçlar doğrultusunda bir sağlık profesyoneline başvurulmalarını sağlamak oldukça önemlidir. Depresyon tanilı hastalarda sorun çözme ve stresle baş etme becerilerinin arttırılması için eğitimler düzenlenerek duygusal yemeye ilişkin farkındalık oluşturulabilir. Ayrıca depresif belirtileri azaltan müdahalelerin de sağlıksız beslenme tarzlarında azalmaya yol açması da mümkündür. $\mathrm{Bu}$ amaçla son yıllarda yaygınlaşan üçüncü kuşak terapilerden olan farkındalık (mindfulness) temelli yaklaşım, duygu düzenleme ve iştah açıcı özellikleri değiştirerek duygusal yemeyi ele almak için kullanılan yaklaşım türlerinden biridir. Bu tarz 
müdahale yaklaşımlarının kullanılmasının da duygusal yemeyi azalttığı bildirilmektedir. ${ }^{74}$

\section{Araştırmanın Etik Boyutu}

Araştırmanın yapılması için Aydın Adnan Menderes Üniversitesi T1p Fakültesi Girişimsel Olmayan Araştırmalar Etik Kurulu Başkanlığı'ndan onay (Protokol No: 2017/1213), İzmir İl Sağl1k Müdürlüğünden ve Aydın Adnan Menderes Üniversitesi Araştırma ve Uygulama Hastanesi Psikiyatri Kliniğinden izinler alınmıştır. Örnekleme alınma kriterlerine uyan hastalara açıklama yapılmış olup hastaların sözlü ve yazılı onamı dahilinde anketler uygulanmıştır.

\section{Bilgilendirilmiş Onam}

Çalışmaya dahil edilen tüm hastalardan imzalı bilgilendirilmiș onam formu alınmıștır.

\section{Yazar Katkıları}

Fikir: S.İ., H.A. Tasarım: S.İ., H.A. Verilerin toplanması ve işlemesi: S.İ. Analiz ve yorum: H.A., S.İ. Literatür taraması: H.A., S.İ. Makale yazımı: H.A., S.İ. Eleștirel inceleme: H.A.

\section{Teşekkürler}

Araştırmaya katılan hastalara teşekkür ederiz.

\section{Çıkar Çatışması Beyanı}

Yazarların herhangi bir çıkar ilişkisi yoktur.

\section{Araştırma Desteği}

Tez Aydın Adnan Menderes Üniversitesi Bilimsel Araştırma Projeleri Birimi tarafından HF-17020 proje numarası ile desteklenmiştir.

\section{Beyanlar}

Yazarların çalışma ile ilgili herhangi bir beyan1 yoktur.

\section{Hakem Değerlendirmesi}

Diş bağımsız.

\section{Kaynaklar}

1. Amerikan Psikiyatri Birliği. DSM-5 Tanı Ölçütleri Başvuru Elkitabı. Köroğlu E, Çev-ed. Ankara, Türkiye: HYB Yayınları; 2013.

2. Küey L. Birinci basamakta depresyon: Tanıma, ele alma, yönlendirme. Psikiyatri Dünyast. 1998;2(1):5-12.

3. Öztürk O, Ulușahin A. Ruh Sağlığ ve Bozuklukları. 15. Baskı. Ankara: Nobel Tip Kitapevleri; 2018.
4. Ișık E, Ișık U, Taner Y. Çocuk, Ergen, Erișkin ve Yaşlılarda Depresif ve Bipolar Bozukluklar. 1. Baskı. Ankara: Ziraat Grup Matbaacilık; 2013.

5. Baysal A. Beslenme. 18. Baskı. Ankara: Hatiboğlu Basım ve Yayınevi: 2007.

6. Konttinen H. Dietary Habits and Obesity: The Role of Emotional and Cognitive Factors [Academic Dissertation]. Helsinki, Finland: Helsinki University; 2012.

7. Tariq AA, Sawsan JH, Alaa MM, Maryam AA, Qaher AM. Emotional eating behavior among University of Bahrain students: A cross-sectional study. Arab Journal of Basic and Applied Sciences. 2019;26(1):424-32.

8. Fairburn CG, Harrison PJ. Eating disorders. Lancet. 2003;361(9355):407-16.

9. De Lauzon-Guillain B, Basdevant A, Romon M, Karlsson J Borys JM, Charles MA. Is restrained eating a risk factor for weight gain in a general population? Am $J$ Clin Nutr. 2006;83(1):132-8.

10. Macht M. How emotions affect eating: A five-way model. Appetite. 2008; 50(1): 1-11.

11. Macht M, Roth S, Ellgring $\mathrm{H}$. Chocolate eating in healthy men during experimentally induced sadness and joy. Appetite. 2002;39(2):147-158.

12. Laitinen J, Ek E, Sovio U. Stress-related eating and drinking behavior and body mass index and predictors of this behavior. Prev Med. 2002;34(1):29-39.

13. Khodabakhsh MR, Kiani F. Effects of emotional eating on eating behaviors disorder in students: The effects of anxious mood and emotion expression. International Journal of Pediatrics. 2014;2(4):295-303.

14. Liu H, Yang Q, Luo J, et al. Association between emotional eating, depressive symptoms and laryngopharyngeal reflux symptoms in college students: A cross-sectional study in Hunan. Nutrients. 2020;12(6):1595.

15. Cecchetto $\mathrm{C}$, Aiello $\mathrm{M}$, Gentili $\mathrm{C}$, Ionta S, Osimo SA. Increased emotional eating during COVID-19 associated with lockdown, psychological and social distress. Appetite 2021;160:105122.

16. Van Strien T. Causes of emotional eating and matched treatment of obesity. Current Diabetes Report. 2018;18(6):35.

17. Jhen-da P. Depression, emotional eating and food choice. Honors College. 2014: 163. https://digitalcommons.library.umaine.edu/honors/163. 01 Subat 2021'de erisildi.

18. Al-Musharaf S. Prevalence and predictors of emotional eating among healthy young Saudi women during the COVID-19 pandemic. Nutrients. 2020;12:(2923):1-17.

19. Paans NPG, Bot M, Brouwer IA, et al. The association between depression and eating styles in four European countries: The MooDFOOD prevention study. Journal of Psychosomatic Research. 2018;108:85-92

20. Rosenbaum DL, White KS. The relation of anxiety, depression, and stress to binge eating behavior. Journal of Health Psychology. 2015;20(6):887-98

21. Hawks SR, Gast JA. Weight loss education: A path lit darkly. Health Education and Behavior. 1998;25(3):371-82.

22. Desmet P, Schifferstein H. Sources of positive and negative emotions in food experience. Appetite. 2008;50(2-3):290-301.

23. Levitan RD, Davis C. Emotions and eating behavior: Implications for the current obesity epidemic. University of Toronto Quarterly. 2010;79(2):783-99.

24. Blackman MC, Kvaska CA. Nutrition Psychology İmproving Dietary Adherence. 1st ed. Massachusetts, Sudbury, Jones and Bartlett Publishers; 2011.

25. Zellner DA, Loaiza S, Gonzalez Z, et al. Food selection changes under stress. Physiol Behav. 2006;87(4):789-93.

26. Ouwens MA, Van Strien T, Van Leeuwe JFJ, Van der Staak CPF. The dual pathway model of overeating. Replication and extension with actual food consumption. Appetite. 2009;52(1):234-7.

27. İnalkaç S, Arslantaş H, Yüksel R. Bir grup ebelik öğrencisinde duygusal yeme ve etkileyen faktörler. Adnan Menderes Üniversitesi 1. Uluslararası Sağlık Bilimleri Kongresi, Aydın; 1 Temmuz, 2017; Aydın, Türkiye.

28. Garaulet M, Canteras M, Morales E, López-Guimera G, Sánchez-Carracedo D, Corbalán-Tutau MD. Validation of a questionnaire on emotional eating for use in cases of obesity; 
the Emotional Eater Questionnaire (EEQ). Nutr Hosp. 2012;27(2):645-51.

29. Seven H. Yetişkinlerde Duygusal Yeme Davranışının Beslenme Durumuna Etkisi [Yüksek Lisans Tezi]. İstanbul, Türkiye: Haliç Üniversitesi; 2013.

30. Arslantaş H, Dereboy F, Yüksel R, İnalkaç S. Duygusal yeme ölçeği'nin Türkçe çevirisinin geçerlik güvenirlik çalışması. Türk Psikiyatri Dergisi. 2020;31(2):122-30.

31. D'Zurilla TJ, Nezu AM, Maydeu-Olivares A. Manuel For The Social Problem Solving İnventory-Revised (SPSI-R), MultiHealth System. North Tonawanda; 2002.

32. Eskin M, Aycan Z. Gözden geçirilmiş sosyal sorun çözme envanteri'nin Türkçe'ye (Tr SSÇE-G) uyarlanması güvenirlik ve geçerlik analizi. Türk Psikoloji Yazıları. 2009;12(23):1-10.

33. Folkman S, Lazarus RS. An analysis of coping in a middleaged community sample. J Health Soc Behav. 1980;21(3):21939.

34. Şahin N, Durak A. Stresle başa çıkma tarzların ölçeği üniversite öğrencileri için uyarlanması. Türk Psikoloji Derneği. 1995;10(34):56-73.

35. Arslantaş H, Dereboy F, İnalkaç S, Yüksel R. Sağlık eğitimi alan üniversite öğrencilerinde duygusal yeme ve etkileyen faktörler. İmir Kâtip Çelebi Üniversitesi Să̆llk Bilimleri Fakültesi Dergisi. 2021;6(1):105-111.

36. Chamberlin A. Academic-Related Factors And Emotional Eating In Adolescents [Master of Science in Nutritional Sciences]. Long Beach- California, USA: California State University; 2015.

37. İnalkaç S, Arslantaș H. Duygusal yeme. Arşiv Kaynak Tarama Dergisi. 2018;27(1):70-82.

38. Cotter EW, Kelly NR. Stress-related eating, mindfulness, and obesity. Health Psychol. 2018;37(6):516-25.

39. Thompson SH, Romeo S. Gender and racial differences in emotional eating, food addiction symptoms, and body weight satisfaction among undergraduates. Journal of Diabetes and Obesity. 2015;2(2):1-6.

40. Candan H, Küçük L. Lise öğrencilerinde yeme bağımlılığı ve etkileyen faktörler. J Psychiatric Nurs. 2019;10(1):12-19.

41. Herle MP, Kan C, Jayaweera K, et al. The association between emotional eating and depressive symptoms: A population-based twin study in Sri Lanka. Glob Health Epidemiol Genom. 2019;4(e4):1-7.

42. Nguyen-Rodriguez ST, Unger JB, Spruijt-Metz D. Psychological determinants of emotional eating in adolescence. Eat Disord. 2009; 17(3):221-24.

43. Wallis DJ, Hetherington MM. Emotions and eating: Selfreported and experimentally induced changes in food intake under stress. Appetite. 2009;52(2):355-62.

44. Macht M, Simons G. Emotions and eating in everyday life. Appetite. 2000;35(1):65-71.

45. Konttinen H, Van Strien T, Männistö S, Jousilahti P, Haukkala A. Depression, emotional eating and long-term weight changes: A population-based prospective study. IntJ BehavNutr Phys Act. 2019;16(1):28.

46. Young D, Limbers CA. Avoidant coping moderates the relationship between stress and depressive emotional eating in adolescents. Eat Weight Disord. 2017;22:683-91.

47. Michopoulos V, Powers A, Moore C, Villarreal S, Ressler KJ, Bradley B. The mediating role of emotion dysregulation and depression on the relationship between childhood trauma exposure and emotional eating. Appetite. 2015;91:129-136.

48. Wit L, Luppino F, Straten A, Penninx B, Zitman F, Cuijpers P. Depression and obesity: A meta-analysis of community-based studies. Psychiatry Research. 2010; 178(2): 230-35.

49. Hemmingsson E, Johansson K, Reynisdottir S. Effects of childhood abuse on adult obesity: a systematic review and meta-analysis. Obesity Reviews. 2014; 15(11): 882-93.

50. Pagoto SL, Schneider KL, Bodenlos JS, et al. Association of post-traumatic stress disorder and obesity in a nationally representative sample. Obesity. 2012; 20(1): 200-5.

51. Rosmond R. Obesity and depression: same disease, different names? Medical Hypotheses. 2004; 62 (6): 976-79.

52. Talbot LS, Maguen S, Epel ES, Metzler TJ, Neylan TC. Posttraumatic stress disorder is associated with emotional eating. Journal of Traumatic Stress. 2013; 26(4): 521-25.
53. Khosravi M. Eating disorders among patients with borderline personality disorder: understanding the prevalence and psychopathology. Journal of Eating Disorders. 2020; 8:38.

54. Maner F. Yeme bozuklukları. Psikiyatri Dünyast. 2001;5:13039.

55. Evers C, Adriaanse M, de Ridder DT, de Witt Huberts JC Good mood food. Positive emotion as a neglected trigger for food intake. Appetite. 2013;68:1-7.

56. Braden A, Musher-Eizenman D, Watford T, Emley E. Eating when depressed, anxious, bored, or happy: Are emotional eating types associated with unique psychological and physical health correlates? Appetite. 2018; 125: 410-17.

57. Soukup VM, Beiler ME, Terrell F. Stress, coping style, and problem solving ability among eating-disordered inpatients. $J$ Clin Psychol. 1990;46(5):592-99.

58. Spoor ST, Bekker MH, Van Strien T, Van Heck GL. Relations between negative affect, coping, and emotional eating. Appetite. 2007;48(3):368-76.

59. Svaldi J, Dorn C, Trentowska M. Effectiveness for interpersonal problem-solving is reduced in women with binge eating disorder. Eur Eat Disord Rev. 2011;19(4):331-41.

60. Kuijer RG, Boyce JA. Emotional eating and its effect on eating behaviour after a natural disaster. Appetite. 2012;58(3):936-9.

61. Geliebter A, Aversa A. Emotional eating in overweight, norma weight, and underweight individuals. Eat Behav. 2003;3(4):341-47.

62. De Young KP, Zander M, Anderson DA. Beliefs about the emotional consequences of eating and binge eating frequency. Eat Behav. 2014;15(1):31-6.

63. Swanson H, Power K, Collin P, et al. The relationship between parental bonding, social problem solving and eating pathology in an anorexic inpatient sample. Eur Eat Disord Rev. 2010;18(1):22-32.

64. Ricca V, Castellini G, Fioravanti G, et al. Emotional eating in anorexia nervosa and bulimia nervosa. Compr Psychiatry. 2012;53(3):245-51.

65. Penaforte FR, Matta NC, Japur CC. Association between stress and eating behavior in college students. Demetra: Food, Nutrition \& Health 2016;11(1):225-37.

66. Van Strien T, Cebolla A, Etchemendy E, et al. Emotional eating and food intake after sadness and joy. Appetite. 2013;66(2013):20-5

67. Polivy J, Herman CP. Distress and eating: Why do dieters overeat? Int J Eat Disord. 1999;26(2):153-64.

68. Temel E, Bahar A, Çuhadar D. Öğrenci hemşirelerin stresle baş etme tarzları ve depresyon düzeylerinin belirlenmesi. Furat Sağlık Hizmetleri Dergisi. 2007;2(5):107-118.

69. Van Strien T, Konttinen H, Homberg JR, Engels RCME, Winkens LHH. Emotional eating as a mediator between depression and weight gain. Appetite. 2016;100:216-224.

70. Konttinen H, Ma"nnisto“ S, Sarlio-La"hteenkorva S, Silventoinen K, Haukkala A. Emotional eating, depressive symptoms and self-reported food consumption. A populationbased study. Appetite. 2010;54:473-479

71. Yılmaz HÖ, Köse G. How does emotional appetite and depression affect BMI and food consumption? Progress in Nutrition. 2020;22(4): e2020088.

72. Aoun C, Nassar L, Soumi S, Osta NE, Papazian T, Khabbaz LR. The cognitive, behavioral, and emotional aspects of eating habits and association with impulsivity, chronotype, anxiety, and depression: A cross-sectional study. Front Behav Neurosci. 2019; 13:204.

73. Kaplan HI, Kaplan HS. The psychosomatic concept of obesity. Journal of Nervous and Mental Disease. 1957;125:181-201.

74. Lattimore P.Mindfulness-based emotional eating awareness training: taking the emotional out of eating. Eat Weight Disord. 2020; 25(3):649-57. 